\title{
Beyond Boyer: SoTL in the Context of Interesting Scholarly Things
}

\author{
Bruce B. Henderson, PhD \\ Professor, Department of Psychology \\ Western Carolina University
}

The positive effects of Ernest Boyer's broader definition of scholarship have been attenuated by stress on published outcomes as indicators of all his scholarships, including the scholarship of teaching and learning (SOTL). At universities outside the research university sector, we need to find ways to recognize and reward a wide variety of interesting scholarly things related to teaching that are not likely to meet the formal assessment criteria that have come to define the SoTL category of scholarship. The faculty's scholarliness in teaching should be recognized and evaluated directly.

There is considerable evidence that university faculty members outside the research university sector have felt increasing pressure since the 1970s to publish scholarly work in order to be awarded tenure, promotion and merit increases (e.g., Boyer, 1990; Milem, Berger, \& Dey, 2000). One concern about this long-standing trend is that faculty members engaged in traditional forms of published scholarship will neglect teaching and public service activities. Perhaps most notably, Boyer (1990) and his colleagues at the Carnegie Foundation felt that the emphasis on publication meant that faculty members who were doing other useful things were not getting sufficient credit. In response to this concern, Boyer and his Carnegie colleagues offered a broader view of scholarship. It included faculty work on teaching (SoTL) and on public service (the scholarship of application or engagement) as well as on more traditional forms of scholarship (the scholarships of discovery and integration). They envisioned universities where a wide array of scholarly activities would be recognized and rewarded. They thought that the broader model of scholarship would be of special help to faculty members at comprehensive universities and small liberal arts colleges where what "counted" as scholarship tended to be most problematic (Boyer, 1990; Leatherman, 1990; Rice, 2005).

The "Boyer Model" has been widely discussed and often included in the evaluation of faculty at many universities of various types over the past two decades (O'Meara, 2005). However, the model has also stimulated controversy. SoTL has proved to be the most controversial aspect of the model in several ways. It has been difficult to define SoTL (Richlin, 2001); SoTL has been seen as an illegitimate form of scholarship (Ziolkowski, 1996); and SoTL has not been linked directly to improved teaching practices (McKinney, 2006). Despite these criticisms, it is clear that SoTL has established itself as an important form of faculty activity.

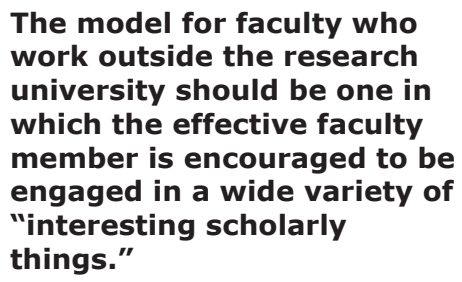

The model for faculty who work outside the research university should be one in which the effective faculty member is encouraged to be engaged in a wide variety of "interesting scholarly things." In this essay, I emphasize SoTL within a broader scope than that which it has come to occupy. Elsewhere (Henderson, 2007; Henderson, in press) I have argued that outside the research university sector, faculty members should not be caught up in the traditional publish-or-perish approach to faculty development and evaluation. Instead, the model for faculty who work outside the research university should be one in which the effective faculty member is encouraged to be engaged in a wide variety of what I term "interesting scholarly things." Indeed, SoTL fits into this broad category of "interesting scholarly things." Central to my argument is the notion that all forms of scholarship have their roots in the scholarliness of faculty members, something that is rarely directly assessed. There are good reasons to avoid using published 
scholarship, including SoTL publications, to indirectly assess a faculty member's scholarliness and good reasons instead to begin to develop means for more directly identifying, developing, and evaluating interesting scholarly things.

\section{Why the Emphasis on Publication?}

In order to put the interesting scholarly things model into perspective, it is useful to explore why the emphasis in developing and evaluating faculty members is so focused on publications. Faculty want to share their ideas and discoveries; they feel a desire and an obligation to be actively involved in their disciplines; and they know the rewards tend to go to those who publish (Fairweather, 2002). But what is behind the external (peer and administrative) pressure at the institutional level on faculty members to publish? One impetus is that there is a strong desire to increase status and prestige (Brewer, Gates \& Goldman, 2002; Rhode, 2006). Status and prestige are sought by most universities, often through imitating those institutions of perceived higher status (Brint, Riddle, \& Hanneman, 2006). Because of resource limitations, of the three major status generators in higher education (Brewer et al., 2002) - selectivity, big-time athletic success, and research-only the research status is practical for most institutions to pursue to "get to the next level." Publications can bring attention to institutions. Unlike good teaching, publications travel well (Winston, 1994) across campuses and across disciplines. Universities use publications to maximize prestige (Brint et al., 2006; Youn \& Price, 2009; Winston, 1994). A second impetus for encouraging faculty publishing is that publications are used as indicators of quality in the tenure and promotion process and, increasingly, in the hiring process. The tacit assumption is that if individuals can produce peerreviewed publications, their teaching and service must be scholarly.

Faculty members at all kinds of colleges and universities perceive that there is increasing pressure to publish. However, outside the research university sector, publishing in meaningful ways presents a number of problems (Marek, 2003). Faculty members do not have the time or physical and fiscal resources for conducting cutting-edge research in many disciplines. At many universities, faculty members need to be generalists (Marek, 2003). They cannot afford to be specialists and their institutions cannot afford for them to specialize. Too much emphasis on specialization at a small or moderately-sized university can limit an institution's flexibility to innovate and to differentiate faculty assignments (Youn \& Price, 2009).

Boyer (1990) recognized that many faculty members at institutions outside the research sector were expected, by themselves and others, to be productive scholars but

The way to demonstrate the new scholarships, especially SoTL, has increasingly taken the form of publications; because of this emphasis on traditional publishing, Boyer's expanded vision of scholarship has realized fewer and fewer practical consequences.

found themselves consumed by the demands of teaching and service. Boyer thought that the broader view of scholarship would be more inclusive, providing those faculty members outside the research university with opportunities to be scholarly and to feel better about themselves (Boyer, 1990). However, the way to demonstrate the new scholarships, especially SoTL, has increasingly taken the form of publications (Boyer, 1996; Glassick, Huber, \& Maeroff, 1997); because of this emphasis on traditional publishing, Boyer's expanded vision of scholarship has realized fewer and fewer practical consequences. Colleges and universities outside the research sector have always celebrated publications in teaching- and engagement-related journals. Thus, using the Boyer model changed how scholarship is functionally viewed very little at most colleges and universities. Even at research universities, where those kinds of publications once might have been seen as third-rate, or more likely, not counted at all, work in SoTL or scholarship of engagement has been seen as a useful add-on to one's résumé, not a substitute for disciplinary scholarship (O'Meara, 2005). 


\section{Interesting Scholarly Things}

Publications in all of Boyer's categories of scholarship are interesting scholarly things. However, there are several reasons why interesting scholarly things should not be limited to publications only. First, scholarly publications are of limited use as prestige generators. There are too many of them, with some estimates of as many as 100,000 journals worldwide (Rhode, 2006). Relatively few publications have an impact. The modal number of times a publication is cited by another is 0 (Hamilton, 1990, 1991; Schwartz, 1997). Relatively few contributors to any field make a significant impact (Allen, 2003; Bensman, 2001; Ioannidis, 2006). Second, publications are of limited usefulness as indicators of quality. The peer review process in the publication world is fraught with problems of disciplinary politics, variation in the quality of referees, and low inter-observer reliability between referees (Weller, 2001). At the local level, publications are frequently counted, not systematically evaluated for their quality (Boyer, 1990). Moreover, no documented connection exists to prove a relationship between publishing (even in SoTL journals) and quality of instruction (Marsh \& Hattie, 2002). Third, publications simply reflect too small a proportion of the many scholarly activities of most faculty members. Within the research university sector, scholarly peer-reviewed publications will probably remain the sine qua non (Daly, 1994). Outside the research university, however, a singular focus on publications makes little sense.

Interesting scholarly things are teaching-, research- and service-related activities that use a scholar's disciplinary expertise. They include publications, but they also include unpublished forms of scholarliness in teaching, research and public service (Braxton, Luckey, \& Helland, 2006).

For example, in teaching they include the Interesting scholarly things scholarly construction of syllabi, modification are teaching-, research- and and updating of lectures, and the service-related activities development of innovative exercises and that use a scholar's assessments. In research they include disciplinary expertise. exploratory research and research projects with students that because of their preliminary nature or distance from the mainstream may be considered un-publishable. In public service they may include the provision of scholarly expertise through consulting of various types or the conducting of workshops for a variety of audiences. These unpublished activities are interesting scholarly things that do not "count" as scholarship at many colleges and universities until they can be converted into publications. Interesting scholarly things do not include obsolete lectures, consulting based on common sense or outdated research, or the chores that must be done at every institution, including most committee work that does not depend on one's expertise.

In the interesting scholarly things model, faculty evaluation and development can be seen as developmental processes. When unpublished faculty activities are scholarly and carefully encouraged and evaluated they may lead to publications. For example, while new faculty members might be intimidated by the idea of doing a full-blown SoTL project, they might respond well to consuming the literature on the pedagogy of their disciplines, sharing teaching ideas and then systematically collecting data on teaching effectiveness.

\section{Consumatory Scholarship}

The common factor in the wide variety of interesting scholarly things, including the unpublished forms of scholarliness, is that they are all based in a faculty member's developing expertise. This expertise comes from what I have called "consumatory" scholarship. "Consumatory" is used here in the sense of consume as "taking in" or "absorbing." The category of interesting scholarly things intentionally blurs the lines between scholarliness and scholarship. Richlin (2001) and others have argued for a clear distinction between SoTL and scholarly teaching 
to elevate SoTL in prestige and visibility, perhaps fearing that disciplines will not accept SoTL as scholarship unless it is similar (especially in terms of peer review) to traditional scholarship. Unfortunately, this emphasis leads to a focus on status and prestige rather than on the underlying quality of faculty work. Also, an emphasis on external peer review limits review to more traditional forms (i.e., publications) and excuses faculty from doing the hard work of developing means for conducting effective evaluation of scholarly teaching, unpublished scholarly research, and scholarly engagement.

\section{SoTL in the Perspective of Interesting Scholarly Things}

Thinking about faculty work as interesting scholarly things has several advantages. For example, SoTL has become an accepted form of scholarship in many settings, yet it is not established that SoTL activities lead to the improvement of teaching (McKinney, 2006). I suspect that like the much touted but mythical relationship between discovery research and teaching, a SoTL-teaching quality connection is unlikely to be found. Yet many interesting scholarly activities that may lead to SoTL (or may never be formalized in that way) probably have a more direct relation to the quality of instruction. These range from relatively minor pedagogical techniques often called "teaching tips" to major course innovations. Central to scholarly teaching is the development of what Shulman (1987) has called pedagogical content knowledge. Pedagogical content knowledge is the thoughtful combining of knowledge of disciplinary concepts, teaching methods, and creative reflection on how concepts and methods can be interwoven in ways that results in student learning. Good teachers at all levels have always engaged in this fundamental activity. It is frequently a trial and error process that evolves over time. I suspect much of the best work in SoTL has involved and will involve the systematization of this scholarly work, based

Pedagogical content knowledge is the thoughtful combining of knowledge of disciplinary concepts, teaching methods, and creative reflection on how concepts and methods can be interwoven in ways that results in student learning.

in pedagogical content knowledge, resulting in traditional peer-reviewed outcomes.

Both the disciplinary knowledge and the pedagogical knowledge in scholarly teaching have their roots in consumatory scholarship. My argument is that all kinds of scholarship, including SoTL, are likely to flourish in climates in which interesting scholarly activities, and the consumatory scholarship they stimulate, are encouraged. The traditional focus on the products of scholarship rather than scholarly process has put the cart before the horse. Let me illustrate with an example from my own recent experience. I am in my fourth decade of teaching child psychology to undergraduate students. Despite many and varied efforts, there are concepts and theories in my discipline that I have had difficulty teaching, as indicated by student performance on exams and in other written work. I am currently trying some new approaches based on what I have read about my discipline and about ways to teach it (my thinking is closely aligned with that of McDevitt \& Ormrod, 2008). What I am doing is scholarly teaching and its scholarliness could be assessed by my departmental peers. I am also systematically studying my new approach with the use of pre- and post-measures, Institutional Review Board (IRB) approval, and documentation of my efforts. If I can show my new approach works, I can write it up and try to get it published in a SoTL journal. If it does get published, it will become SoTL instead of just scholarly teaching. If it does not succeed, it will not be published (failures, no matter how instructive, are essentially impossible to get published), but my effort will remain an interesting scholarly thing that nonetheless should be recognized and evaluated. 


\section{Interesting Scholarly Things and Student Learning}

What might the interesting scholarly things model do for student learning? In the preface of his 1990 book, Boyer expressed his concern about the effect of focusing on faculty publishing on teaching and learning. His expanded view of scholarship was designed to broaden what "counts" in faculty assessment to include the scholarly improvement of teaching and work with students. The interesting scholarly things model "counts" those scholarly activities closest to students, including pedagogical innovations, informal research projects, and service-learning that has a scholarly base. When scholarly work with students leads to paper presentations or publications, so much the better, but learning can occur when it does not result in peer reviewed articles.

\section{Objections}

A number of likely objections to the interesting scholarly things model can be anticipated. I will address a few that have particular relevance to SoTL.

Slouching toward scholardom. Ziolkowski (1996) argues that broadening the concept of scholarship weakens it. Just as the core beliefs of Christianity were diluted in the development of the "official Christianity" of the European state churches (Christendom), using the term "scholarship" to refer to activities other than traditional research and publication makes it meaningless. Faculty members will want credit for chairing the social committee, traveling abroad to gain teachingrelated experience, publishing in the local gardening newsletter, or belonging to the local service clubs. The model of interesting scholarly things prevents dilution of that kind. It suggests that we attend to the scholarliness of everything we do. The faculty member who claims credit for an activity (teaching, service, or research) would have to demonstrate how it reflects disciplinary expertise.

The scholarly pumpkin. The concern with devolution into scholardom has a special application in regard to SoTL. Quality control has been a central issue in debates about SoTL (Dewar, 2008). I recently talked with the members of a department of mathematics resistant to adding requirements of any form of scholarship to their annual review and tenure documents. I suggested that there were many different kinds of useful and interesting scholarly things they could (and should) be doing, such as finding better

\section{Faculty members who want credit for doing interesting scholarly things need to be able to show how those things reflect their scholarly expertise in meaningful ways.} ways to teach mathematics to the many students who struggle with math. One faculty member responded that he had carved mathematical symbols into a pumpkin one Halloween, but that he did not think that was scholarship. Nor is it an interesting scholarly thing. Faculty members who want credit for doing interesting scholarly things need to be able to show how those things reflect their scholarly expertise in meaningful ways (Andresen, 2000).

Measuring interesting scholarly things. There are challenges to measuring a wide array of interesting scholarly things. New forms of peer review involving different kinds of peers inside and outside one's units and disciplines are required. Regional consortia may be needed to share peer review responsibilities across institutions and disciplines. There are technical issues with all kinds of peer review (Weller, 2001) but the issues in evaluating interesting things are less questions of technical possibility than of the willingness to make the effort to find new ways of judging faculty work. Perhaps too much energy has been spent trying to distinguish what is and what is not SoTL. Assessing a broader range of interesting scholarly things should reduce the likelihood of border wars about what does and does not "count." However, until unpublished interesting scholarly things are considered to be important enough to measure, the hard work of developing ways to measure them within disciplines will not occur. 
Issues of collegiality. A concern many faculty members and administrators have about faculty evaluation is the effect of collegial relationships on objectivity. Peer reviews by those within one's own unit are seen as being ineffective or useless either because peers are too positive or too petty. I am not so naïve to believe this is not a problem. But I am also convinced that academics are smart enough to develop professional attitudes and control mechanisms that can minimize the effects of a loss of objectivity. Regional inter-institutional arrangements like those referred to above are one mechanism, but the possibility of effective intra-institutional mechanisms should not be abandoned. Many SoTL and scholarly teaching activities can be evaluated across disciplines, lessening the bureaucratic difficulties of peer review within smaller units.

The accrediting agencies say we have to do research. Administrators at all kinds of colleges and universities push their faculties to do more research and publication (Youn \& Price, 2009). They are creatures of the culture that for some 60 years has provided a single standard for judging the quality of faculty members and institutions, the publication of books and articles in peer-reviewed journals (Lynton, 1983). Imitation of institutions whose faculties are most successful at meeting this standard has led to the snake-like procession Riesman (1965) described many years ago. The most commonly heard cries for more traditional scholarship are "we won't get accredited if we don't publish more" and "we need to take this institution to the next level." However, not all faculty members need to be doing traditional forms of scholarship all the time or throughout their careers. On the other hand, all faculty members should be doing interesting scholarly things all the time and throughout their careers.

The status/prestige problem. Perhaps the single greatest source of problems for the interesting scholarly things model is the attitude that activities (including SoTL) other than traditional scholarship and publication are simply not important enough to count (Braxton \& Del Favero, 2002). Real scholars publish; that is all there is to it. This problem may be insurmountable in the research university where faculty members who spend a lot of time on SoTL activities do so at their own peril (Daly, 1994; Shapiro, 2006). At comprehensive universities and liberal arts colleges, however, strong leadership should be able to overcome the hegemony of the research university model. It will not be easy. All faculty members with doctorates are prepared to be publishing scholars and, too often, to look down upon those who are not (ironically, whether or not they are publishing scholars). They are not generally wellprepared for the kinds of jobs outside the research university sector most of them obtain (Austin, 2002). The truth is that there really is

The even broader category of interesting scholarly things may be able to find acceptance in the comprehensive universities and liberal arts colleges, thus allowing the development of distinctive missions and breaking the procession of institutions mindlessly following the lead of the research universities.

not that much traditional scholarship and publishing going on at the comprehensive universities and most of the liberal arts colleges (e.g., Toutkoushian, Porter, Danielson, \& Hollis, 2003). On many campuses, the ratio of rhetoric about publishing to the reality of publishing is quite high. On the other hand, SoTL-related publishing has been shown to be a special niche for faculty members at comprehensive universities and liberal arts colleges (Henderson \& Buchanan, 2007). The even broader category of interesting scholarly things may be able to find acceptance in the comprehensive universities and liberal arts colleges, thus allowing the development of distinctive missions and breaking the procession of institutions mindlessly following the lead of the research universities (Morphew, 2002). 


\section{Conclusion}

Faculty members do all kinds of interesting scholarly things. In our current systems of faculty development and rewards, the faculty members who get recognition are those who garner prestige by becoming published scholars. Yet what may be most important to the central mission of the majority of colleges and universities, to the learning of students and to the development of effective teaching, are those scholarly activities resulting from consumatory scholarship in disciplines and pedagogy that never get reviewed by peers from outside one's institutional units. These more "local" activities, including nascent forms of SoTL and scholarly teaching, can be reviewed and evaluated if faculty members will make the time and effort to develop ways to do so (Diamond, 2002; Trower, 2000).

\section{References}

Allen, W. B. (2003). Habits of mind: Fostering access and excellence in higher education. New Brunswick, NJ: Transaction Publishers.

Andresen, L. W. (2000). A useable, trans-disciplinary conception of scholarship. Higher Education Research \& Development, 19(2), 137-153.

Austin, A. E. (2002). Creating a bridge to the future: Preparing new faculty to face changing expectations in a shifting context. Review of Higher Education, 26(2), 119-144.

Bensman, S. J. (2001). Urquhart's and Garfield's laws: The British controversy over their validity. Journal of the American Society for Information Science and Technology, 52(9), 714-724.

Boyer, E. L. (1990). Scholarship reconsidered: Priorities of the professoriate. Princeton, NJ: Carnegie Foundation for the Advancement of Teaching.

Boyer, E. L. (1996). From scholarship reconsidered to scholarship assessed. Quest, 48(2), 129-139.

Braxton, J. M., \& Del Favero, M. (2002). Evaluating scholarship performance: Traditional and emergent assessment templates. New Directions for Institutional Research, 114, 19-32.
Braxton, J. M., Luckey, W., \& Helland, P. (2006). I deal and actual value patterns toward domains of scholarship in three types of colleges and universities. New Directionsfor Institutional Research, 129, 67-76.

Brewer, D. J., Gates, S. M., \& Goldman, C. A. (2002). In pursuit of prestige: Strategy and competition in U.S. higher education. New Brunswick, NJ: Transaction Publishers.

Brint, S., Riddle, M., \& Hanneman, R. A. (2006). Reference sets, identities, and aspirations in a complex organizational field: The case of American four-year colleges and universities. Sociology of Education, 79(3), 229-252.

Daly, W. T. (1994). Teaching and scholarship: Adapting American higher education to hard times. Journal of Higher Education, 65(1), 45-57.

Dewar, J. M. (2008). An apology for the scholarship of teaching and learning. Insight: A Journal of Scholarly Teaching, 3, 17-22.

Diamond, R. M. (2002). Defining scholarship for the twenty-first century. New Directions for Teaching and Learning, 90, 73-79. 
Fairweather, J. S. (2002). The mythologies of faculty productivity: Implications for institutional policy and decision making. Journal of Higher Education, 73(1), 26-48.

Glassick, C. E., Huber, M. T., \& Maeroff, G. I. (1997). Scholarship assessed: Evaluation of the professoriate. San Francisco: JosseyBass.

Hamilton, D. P. (1990, December 7). Publishing by-and for-the numbers: New evidence raises the possibility that a majority of scientific papers make negligible contributions to knowledge. Science, 250, 13311332.

Hamilton, D. P. (1991, January 4). Research papers: Who's uncited now? Science, 251, 25.

Henderson, B. B. (2007). Teaching at the people's university: An introduction to the state comprehensive university. San Francisco, CA: Jossey Bass/Anker Series.

Henderson, B. B. (in press). Mission creep and teaching at the master's university. College Teaching.

Henderson, B. B. \& Buchanan, H. E. (2007). The scholarship of teaching and learning: A special niche for faculty at comprehensive universities? Research in Higher Education, 48(5), 523-543.

Ioannidis, J. P. A. (2006). Concentration of the most-cited papers in the scientific literature: Analysis of journal ecosystems. PLoS one, 1(1), e5. Retrieved September 11,2008 from http://www. plosone. org/article/info: d oi\% 2F10.1371\% 2Fjournal. pone. 0000 005

Leatherman, C. (1990, December 5). Definition of faculty scholarship must be expanded to include teaching, Carnegie Foundation says. Chronicle of Higher Education, 37, A1, A16-
Lynton, E. A. (1983). A crisis of purpose: Reexamining the role of the university. Change, 15, 18-23, 53.

Marek, J. (2003). Scholarship Reconsidered ten years after and the small college. Profession 2003, 4454.

Marsh, H. W., \& Hattie, J. (2002). The relation between research productivity and teaching effectiveness: Complementary, antagonistic, or independent constructs? Journal of Higher Education, 73(5), 603-641.

McDevitt, T. M., \& Ormrod, J. E. (2008). Fostering conceptual change about child development in prospective teachers and other college students. Child Development Perspectives, 2(2), 85-91.

McKinney, K. (2006). Attitudinal and structural factors contributing to challenges in the work of the scholarship of teaching and learning. New Directions for Institutional Research, 129, 37-50.

Milem, J. F., Berger, J. B., \& Dey, E. L. (2000). Faculty time allocation: A study of change over twenty years. Journal of Higher Education, 71(4), 454-475.

Morphew, C. C. (2002). A rose by any other name: Which colleges become universities? Review of Higher Education, 25(2), 207-223.

O'Meara, K. A. (2005). Encouraging multiple forms of scholarship in faculty reward systems: Does it make a difference? Research in Higher Education, 46(5), 479-510.

Rhode, D. L. (2006). In pursuit of knowledge: Scholars, status, and academic culture. Stanford, CA: Stanford Law and Politics. A17. 
Rice, R. E. (2005). Scholarship reconsidered: History and context. In K. A. O’Meara \& R. E. Rice (Eds.), Faculty priorities: Rewarding multiple forms of scholarship (pp. 17-31). San Francisco: Jossey-Bass.

Richlin, L. (2001). Scholarly teaching and the scholarship of teaching. New Directions in Teaching and Learning, 86, 57-68.

Riesman, D. (1965). Constraint and variety in American education ( $2^{\text {nd }}$ ed.). Lincoln, NE: University of Nebraska Press.

Schwartz, C. A. (1997). The rise and fall of uncitedness. College and Research Libraries, 58(1), 19-29.

Shapiro, H. N. (2006). Promotion and tenure and the scholarship of teaching and learning. Change, $38(2), 38-43$.

Shulman, L. S. (1987). Knowledge and teaching: Foundations of the new reform. Harvard Educational Review, 57(1), 1-22.
Toutkoushian, R. K., Porter, S. R., Danielson, C., \& Hollis, P. R. (2003). Using publications counts to measure an institution's research productivity. Research in Higher Education, 44(2), 121-148.

Trower, C. A. (Ed.). (2000). Policies on faculty appointment: Standard practices and unusual arrangements. Bolton, MA: Anker.

Weller, A. C. (2001). Editorial peer review: Its strengths and weaknesses. Medford, NJ : Information Today.

Winston, G. C. (1994). The decline in undergraduate teaching: Moral failure or market pressure? Change, 26(5), 8-15.

Youn, T. I. K., \& Price, T. M. (2009). Learning from the experience of others: The evolution of faculty tenure and promotion rules in comprehensive institutions. Journal of Higher Education, 80 (2), 204-237.

Ziolkowski, E. J. (1996). Slouching toward scholardom: The endangered American college. College English, 58(5), 568-588.

Bruce Henderson is a Professor of Psychology at Western Carolina University. He received his PhD in Child Psychology from the University of Minnesota and conducts research in both developmental psychology and the scholarship of teaching and learning. Specifically, he has research interests in curiosity and exploratory behavior, development of intrinsic motivation, memory development, effects of school bus experiences on child development, and issues in higher education. 